\title{
Governing networks in tourism: What have we achieved, what is still to be done and learned?
}

\author{
Michael Volgger and Harald Pechlaner*
}

\author{
Michael Volgger \\ European Academy of Bozen-Bolzano (EURAC research) \\ Address: Drususallee 1/VialeDruso 1 \\ 39100 Bozen/Bolzano, Italy \\ Email: michael.volgger@eurac.edu \\ Phone: +390471055325 \\ Fax: +390471055429 \\ Harald Pechlaner \\ Catholic University Eichstätt-Ingolstadt and \\ European Academy of Bozen-Bolzano (EURAC research) \\ Address: Drususallee 1/Viale Druso 1 \\ 39100 Bozen/Bolzano, Italy \\ Email: harald.pechlaner@eurac.edu \\ Phone: +390471055420 \\ Fax: +390471055429
}

\footnotetext{
* This is an author generated postprint version (with author's formatting) of the article:

Volgger, M., \& Pechlaner, H. (2015). Governing networks in tourism: what have we achieved, what is still to be done and learned?. Tourism Review, 70(4), 298-312.

The final publication is available at http://dx.doi.org/10.1108/TR-04-2015-0013
} 


\section{Governing networks in tourism: What have we achieved, what is still to be done and learned?}

\section{Structured abstract}

Purpose: Networks and networking are ubiquitous concepts in tourism, their importance appreciated by scholars and practitioners. Tourism research has developed elaborate methods and concepts to grasp the numerous variants of tourism networks and to gain insights into their governance. In particular, AIEST and its official journal, Tourism Review, have made significant contributions to the achievements in this research area. After approximately two decades of intensive research on tourism networks, it is appropriate to pause for a moment to critically assess the results achieved, to compare them with partly old, partly newly emerging real-world challenges, and to explore future directions.

Design/methodology/approach: This paper provides a selective and critical overview of the state-of-the-art in research on governing networks in tourism. This overview of eight major achievements is combined with an exploratory, comparative analysis of qualitative interviews with tourism practitioners.

Findings: Considering the two sources mentioned above, the study derives seven suggestions for future directions in research on network governance in tourism. These relate to the big picture of tourism governance, e-governance, disparities within networks, negative aspects of networking, dynamism of networks, network moderators and means of network steering.

Originality/value: Due to its design, the paper is uniquely able to compare real-world issues with up-to-date theoretical achievements, and will contribute to bringing them closer together in future approaches. Hence, it is relevant for both academic readers and practitioners.

Key words: governance, network, leadership, tourism, stakeholder involvement, collaboration

Article classification: Research paper

\section{Introduction}

Recent tourism research is characterised by a consolidating and expanding interest in the topic of networks and their governance. This holds particularly true for issues concerning the management and development of networks in tourism destinations (Dredge, 2006a). Indeed, 
the governance of networks has been among the most considered topics in tourism research overall. About five percent of all indexed tourism publications reserve a prominent position for discussing networks. Specifically, searching for the pair of keywords "network and tourism" on the SCOPUS abstract database of peer-reviewed literature returns 2,372 results, considering all publication years and all document types (compared to 47,004 results altogether for the sole keyword "tourism"); searching for "network and tourism and governance or governing" on the SCOPUS database still produces 98 hits (April 2015).

This paper positions this relevant portion of tourism research literature in the context of current challenges and real-world developments and proposes suggestions for future research efforts. It starts by critically assessing the state-of-the-art research on the governance of networks in tourism. This critical review does not aim to be comprehensive, but rather to highlight a number of strengths and weaknesses of existing research. Based on a few empirical analyses, it then derives some issues for future research. These future prospects particularly consider aspects of relevance and the ability to move the field forward.

\section{Literature review}

The literature review looks back to what research on governing networks in tourism has achieved so far. This section starts by listing, and later briefly describing, what may be main accomplishments:

- Consolidating the understanding of tourism as a networked system;

- Inspecting desirable outcomes of networking;

- Making a paradigmatic step from management to governance;

- Classifying approaches to tourism network governance;

- Developing and applying methods to describe networks;

- Developing insights into how networks can be promoted: Fostering cooperation and collaboration;

- Understanding coordination processes in networks;

- Scrutinizing the role of specific actors in network management. 


\subsection{Consolidating the understanding of tourism as a networked system}

The idea of a systemic nature of tourism has been well established, starting from the subdivision of tourism into its principle and interconnected subsystems (Kaspar, 1991; Leiper, 1990), and progressing to the appreciation of tourism as a complex system with chaotic as well as adaptive characteristics (Baggio, 2008; McKercher, 1999; Russell and Faulkner, 2004).

The network focus has contributed to this understanding, especially at the interface of private and public domains (see Scott et al., 2008) and in relation to various directions of cooperative behaviour and partner selection: along the value chain (Zhang et al., 2009), as "horizontal" networks (Fyall and Garrod, 2005; Volgger et al., 2013) and as "diagonal" networks in destinations (Bieger, 1996; Fyall et al., 2012). Although a few contributions have highlighted interrelationships with external systems such as location management and regional innovation systems (Bieger and Scherer, 2003; Pechlaner et al., 2012; Weidenfeld, 2013), some weaknesses are apparent in fitting the insights from sub-networks of tourism into the big picture of the tourism system and its environment. Additionally, we might perceive the weakness of some work that scrutinizes supply-chain networks and demand-side networks separately or disregards the role of demand-side networks altogether.

\subsection{Inspecting desirable outcomes of networking}

Tourism literature generally considers networks, collaboration and partnerships as desirable (inter-)organizational structures to promote sustainability and commercial effectiveness as well as profitability. Due to the bundled nature of many tourism products, the predominance of fragmented small and medium sized firms and the role of community owned resources, many researchers consider inter-organizational cooperation as an important factor in tourism destinations (Fyall et al., 2012; Scott et al., 2008; Candela and Figini, 2010). These peculiarities of tourism destinations may be met by establishing responsive and close ties between industry and policy, and tourism research (Novelli et al., 2006; Tinsley and Lynch, 2008). Moreover, the involvement of a broad set of stakeholders may facilitate sustainable tourism development (Bramwell and Lane, 2000, 2011; Jamal and Getz, 1995). However, the organizational complexity present in the context of tourism destinations, especially when conceived as comprising a broad set of stakeholders, requires special consideration.

Network approaches may be able to address this complexity (Bramwell and Lane, 2000; d'Angella and Go, 2009; Dredge, 2006b; Dredge and Thomas, 2009), but sometimes tend to 
limit this potential by a bias towards mostly evaluating networks under positive premises. While risks of networking are acknowledged (Bramwell and Lane, 2000; Hall, 1999; Pechlaner and Volgger, 2012), detailed investigations of these risks remain to be developed. Studies form outside of tourism may provide insightful inspiration in this regard (see e.g. Kale and Anand, 2006; Sammarra and Biggiero, 2008).

\subsection{Making a paradigmatic step from management to governance}

Deeper considerations of the complexities involved in organizing inter-organizational networks such as destinations led to a major paradigmatic step in tourism destination research. Initially, tourism research emphasized a nexus between comprehensive management of tourism destinations as strategic units and the success and competitiveness of these destinations (Bieger, 1996; Buhalis, 2000; Ritchie and Crouch, 2003). Hence, tourism research saw an affirmation of the management perspective in destinations ('destination management') and learned that destinations (i.e. networks) can be steered and strategically aligned. Subsequently, driven by related studies in other fields and disciplines (e.g. Mayntz, 2004; Rhodes, 1997; Williamson, 1979), tourism research increasingly recognized discrepancies in applying one-dimensional corporate approaches to tourism destinations. Research appreciated that inter-organizational networks such as destinations require somewhat different forms of organizing and steering than hierarchically structured firms (Beritelli et al., 2007). These differences were captured in the notion of destination governance (Laws et al., 2011; Nordin and Svensson, 2007; Pechlaner et al., 2010; Raich, 2006; Ruhanen et al., 2010). Authors concluded that to be effective, efficient, sustainable, legitimate and accepted, network coordination should take the form of stakeholder-oriented and participative governance rather than top-down management (Pechlaner et al., 2015).

Although reflections on corporate governance may provide a valuable point of departure for discussions on destination governance, in the network context of destinations, informal mechanisms, trust and knowledge are relatively more important than in firms (Beritelli et al., 2007). But what does this mean for destination managers (or destination governors) in tangible and concrete terms? While the insights offered by destination governance are significant and relevant, it is at least questionable whether they have been fully understood and received in practice. 


\subsection{Classifying approaches to tourism network governance}

In a widely cited paper, Flagestad and Hope (2001) introduced a basic distinction between corporate and community-based approaches to destination governance. Subsequently, this distinction has been refined and complemented (Bodega et al., 2004; d'Angella et al., 2010). While appreciating these efforts, Beaumont and Dredge (2010) rightly identify a gap in comparative research in tourism governance relating to investigating the consequences of different governance approaches. To partially fill this gap, they compared various approaches of destination governance in terms of effectiveness and identified a number of trade-offs concerning potential output variables of governance (efficiency vs. inclusiveness, internal vs. external legitimacy, flexibility vs. stability). Thus, their findings indicate that no panaceagovernance form exists, but that to a relevant degree the evaluation of particular governance approaches depends on the specific objectives. Whereas DMO-led networks may be more dynamic and authoritative within the industry, council-led governance may be better equipped with financial resources and a decentralized, participant-led network may be the most inclusive governance scheme.

In summary, existing research has produced numerous descriptive models, with a diverse set of dimensions, for classifying approaches in destination governance. However, research has only made the first steps from such descriptive approaches towards causal models that try to link specific governance arrangements to various outcomes (such as effectiveness, efficiency, legitimacy, dynamism etc.). Again, a detailed analysis of (inter-)linkages between supply-side and demand-side-factors would be especially desirable. While in general terms tourism shares this gap with other research areas, it is possible to find some initial attempts to establish such a link outside tourism (see e.g. Chung and Luo, 2008; Kurtz and Schrank, 2007).

\subsection{Developing and applying methods to describe networks}

On the methodological side, stakeholder analysis (Getz and Jamal, 1994; Jamal and Getz, 1994) and network analysis (Del Chiappa and Presenza, 2013; Pforr, 2006; Pforr et al., 2014; Scott et al., 2008; Shih, 2006) have made it more possible to capture and represent destination networks and their major actors. These analyses help classify types of destination stakeholders and identify their relationships. These instruments are useful for realizing and capturing the structure of a destination, but only implicitly reveal processes and dynamics. While recently reflections on dynamic applications have intensified, further development and application of more dynamic representations are required. Points of departure for such methodological 
considerations could be dynamic network analysis tools such as those presented by Carley et al. (2007).

\subsection{Developing insights into how networks can be promoted: Fostering cooperation and collaboration}

Cooperation is "about work[ing] jointly towards the same end" (Pearsall, 2001). Due to fragmented supply paired with bundled consumption of tourism products, inter-organizational cooperation has rather obvious benefits (Fyall et al., 2012; Scott et al., 2008).

However, Augustyn and Knowles (2000) and Pechlaner and Volgger (2012) indicate that strategic and resource interdependence is a necessary, but not sufficient condition for actors to engage in inter-organizational collaboration in tourism destinations. Additionally, risks of opportunistic behaviour need to be mitigated and related transaction costs reduced, through organizations, processes and personal traits or cultural values. Hence, they underscore that cooperation and an attitude of engaging in networks can be promoted by organizational and procedural measures or through relational leadership.

\subsection{Understanding coordination processes in networks}

Engagement in networking is considered as increasing competitiveness of actors and groups of actors. Beaumont and Dredge (2010) and Raich (2006) underscore the importance of shared objectives in the governance of networks. However, shared objectives cannot be assumed a priori. Therefore, some authors emphasize the critical role of coordination and relational quality (Andreu et al., 2010). Beyond infrastructural and service quality, it is often beneficial when tourism destinations feature a high quality in social relationships and coordination. The basis of a coordinated network agency comprises among other things social capital, network-specific investments, pooling of complementary resources, mutual sharing of knowledge and learning communities (Bachinger, 2014).

Within such "dormant" or latent networks with at least partially diverging objectives (i.e. the usual case), actors use different resources to steer and influence the orientation of the collective agency. The most prominent among these resources are formal power, money, knowledge and trust (Raich, 2006). In particular, tourism research has investigated the role of knowledge and trust in steering networks (Beritelli and Laesser, 2011; Ford et al., 2012; Nunkoo et al., 2012). Whereas formal power has been considered in the form of tourism policy networks (Airey and Chong, 2010; Dredge, 2006b; Pforr, 2006; Stevenson et al., 
2008), investigations into the respective roles of money, funding and investment schemes in destination governance are scant. Additionally, inspirational behaviour that motivates actors towards willingly accepting common objectives in tourist destinations, i.e. destination leadership, has received less attention.

\subsection{Scrutinizing the role of specific actors in network governance}

Destination management or marketing organizations (DMOs) are one of the most studied organizational set-ups to deal with the issue of cooperation and governance in destinations. They are seen as a useful means to promote collaboration and networking within and sometimes even across destinations (Buhalis and Cooper, 1998; Fyall et al., 2012; Manente and Minghetti, 2006).

Among others, Gretzel et al. (2006), Pechlaner et al. (2012), Dredge (2006b), Bornhorst et al. (2010) and Volgger and Pechlaner (2014) scrutinized factors for DMO success. They argued that DMOs need to account for stakeholder involvement, efficiency, professionalism and provide transparent evidence for success (effectiveness). Thus, it became increasingly clear that networking capability plays an important role in ensuring DMO success. Others underscored the changing requirements and roles for DMOs (Beritelli et al., 2014).

However, what about the roles of other actors in destination governance? While a few contributions acknowledge the importance of individual entrepreneurs (Komppula, 2014; Pavlovich, 2011, 2003) and their thematic partnerships and consortia (Volgger et al., 2013), additional research on tourism entrepreneurship in networks in general, and in destinations in particular is required. For instance, and again highlighting a marked lack of research into the interface of tourism supply-side and demand-side networks, a profound discussion of the role of tour operators and other market-oriented gatekeepers in tourism network governance is still mostly lacking.

\section{Data and Methodology}

To inspire further reflection on the future needs for research into governing networks in tourism, and to investigate the most relevant issues for tourism practitioners, we conducted an exploratory comparative (re-)analysis (meta study) of five qualitative studies on destination development and management in the Alpine area (South Tyrol, Austria and Bavaria) that we completed between the years 2012 and 2014. We analysed the empirical material, comprising 53 semi-structured interviews conducted with various actors in tourism (including destination 
managers, hoteliers and managers of attraction points; see Table 1), with the GABEK analysis method (Pechlaner and Volgger, 2012; Zelger, 2000).

\begin{tabular}{lc}
\hline Interviewee affiliation & Frequency \\
\hline Destination organisation & 24 \\
Accommodation business (and their consortia) & 15 \\
Attraction point (including ski resorts) & 13 \\
Regional development organisation & 1 \\
\hline Sum & 53 \\
\hline
\end{tabular}

Table 1: Affiliations of the interviewed individuals

All interviews were semi-structured with a number of open guiding questions that also allowed for follow-up questioning. This openness allows interviewees to deliver their thoughts and relevance structures ("perceptions"), reducing the impact of the interviewees' considerations and presuppositions (Gephart, 2004; Zelger, 2000). The interviews were recorded and transcribed.

A GABEK-driven analysis, which has its foundations in phenomenological gestalt theory (Stumpf, 1939), guides the researcher in coding this "raw data" of transcribed interviews in the form of interconnected keywords. This coding process, as carried out in this meta-study, can be divided into three phases, where phase 1 and phase 2 had already been carried out in the corresponding case studies (a detailed description can be found in Pechlaner and Volgger, 2012):

(1) Definition of text units: The researcher divides the interview texts into semantically "closed" statements, that convey an idea (similar to paragraphs);

(2) Coding of keywords: The researcher codes each text unit (above) with three to nine keywords, that should be individually selected as close as possible to the interviewees' own terms, and as a set, represent the core idea of the underlying text unit;

(3) Display of association graphs: Based on the previous coding steps, GABEK allows one to display the whole set of interviewees' statements as network(s) of keywords, where those keywords (nodes) are connected (share a common edge) that appear together in at least one text unit (see step 1); GABEK allows one to display so-called "ego networks" (i.e. sub-networks that start from a single node) of varying degrees and different levels of detail, depending on the research question; 
(4) Definition of higher-order categories: Based on the research question and existing theory, the researcher may group the keywords in the derived association graphs of (sub-) networks into subsets of higher-order categories, in order to identify patterns and facilitate theory building (see e.g. Simon, 1962, who defines searching for patterns in phenomena as a key task of science).

Thus, overall GABEK allows one to consider interview sets as semantic networks on a keyword basis and identify semantic associations as perceived by interviewees. The specific objective of the meta-analysis that underlies this study was to explore interviewees' associations with the network concept. However, since our literature review above on previous achievements has outlined a potential lack in considering the interface between supply-and-demand side sub-networks, a secondary objective in this exploratory study was to look for possible touch points of tourism network concepts with the demand side (or better: with demand side-related concepts), as perceived by the interviewees.

In accordance with these objectives, in this meta-study two GABEK analyses of the coded interview data were carried out: (1) the construction of a semantic "ego" network around the central keyword 'network'; and (2) the construction of a semantic "ego" network around the central keyword 'guest', being a (if not the) crucial demand side concept in tourism in general, as well as a concept with various connections within the specific data set. This second, more specific analysis was deemed necessary because the first general part did not reveal any direct connections between the network-concept and clearly demand-related concepts such as 'guest' or 'tourist'.

By considering in both analyses only semantic connections that appeared at least three times in the various interviews, we were able to concentrate on a number of major themes and issues that interviewees from tourism practice related to governing networks in tourism.

\section{Results}

A number of keywords that interviewed Alpine tourism stakeholders associated with networks and their governance in our qualitative studies are indicated in Figure 1; this presents the output of the first part of the GABEK analysis, the semantic "ego" network around the central keyword 'network', as present in the interviewees' statements. 
Figure 1: Issues and themes that interviewees associate with networks in tourism

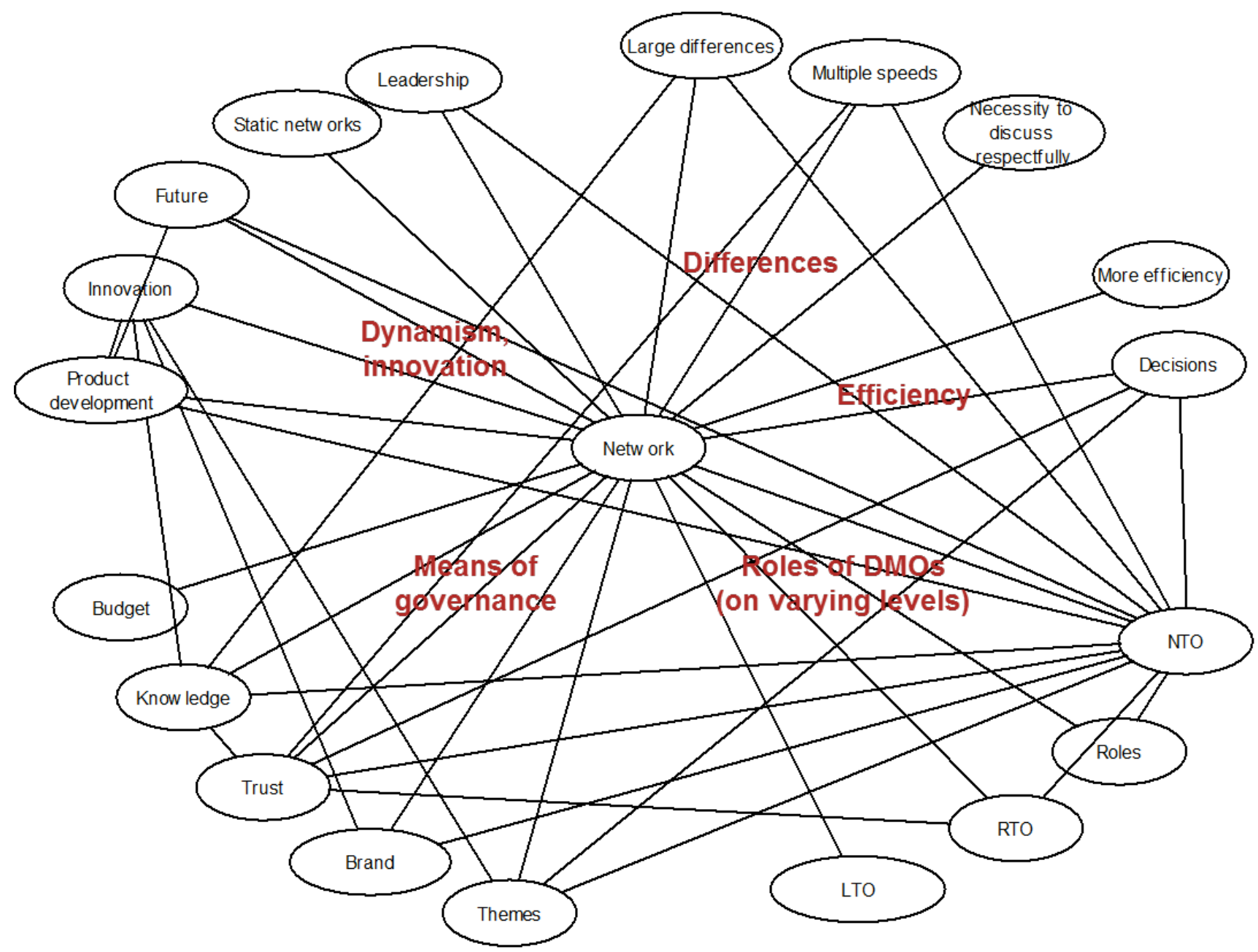

Note: Associations are shown by a shared line between keywords. Interviewees mentioned all shown associations at least three times.

Based on network governance theory, the displayed keywords connected with the central keyword 'network' may be arranged into five broad core themes or 'higher-order categories' (see step 4 of the GABEK analysis phases above):

- Dynamisms and innovation: In different instances, interviewees' associations with tourism networks included a time dimension and references to change, such as product development and innovation. According to interviewees, leadership seems to be a relevant construct when explicating the link between tourism networks and change.

- Differences: Interviewees associated tourism networks with the issue of differences between network members. Network governance, networking outcomes and the 
promotion of networks need to consider the issue of differences, according to interviewees.

- Efficiency: Interviewees request tourism network governance to (more) strongly consider efficiency. They argue that the ability to take decisions, despite possible existing differences in opinions and characteristics (see point before), may be a central tenet of efficient network governance.

- Means and instruments of network governance: Interviewees mention several instruments that may be employed to coordinate and govern tourism networks. Some of them are already well established in theory (such as budget, trust, knowledge); others are less frequently discussed in existing literature (such as brands and themes).

- Roles of DMOs at different levels of tourism governance: Interviewees associate tourism networks with reflections of the role of specific actors, especially tourism organisations and DMOs. They discuss the distribution of roles between DMOs at different levels (national, regional, etc.) and between DMOs and tourism entrepreneurs, as well as additional destination actors.

Interviewees did not seem to associate the concept of tourism networks directly with demandrelated concepts (see Fig.1). However, the outcomes of our literature review suggested that neglecting interfaces between demand and supply-side networks might be a potential gap in existing research on tourism network governance. Hence, to explore potential touch points with the demand side, which future studies could elaborate upon, we purposely added an analysis of the interviewees' associations with the keyword 'guest' (see Fig. 2). 
Figure 2: Interviewees' associations with the keyword 'guest'

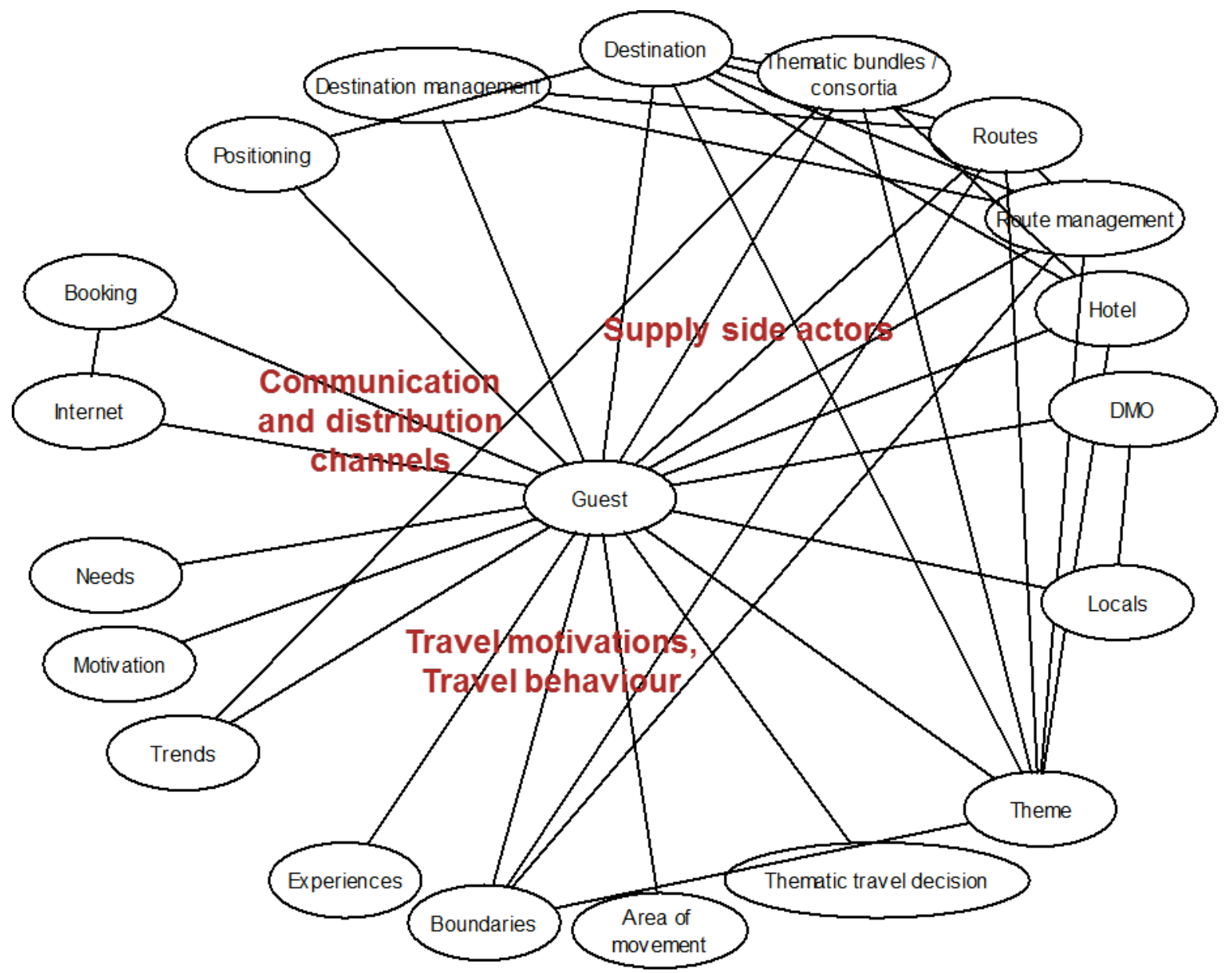

Note: Associations are shown by a shared line between keywords. Interviewees mentioned all shown associations at least three times.

Figure 2 presents the output of the second part of the GABEK analysis, i.e. the semantic "ego" network around the central keyword 'guest'. The displayed keywords that are connected with the central keyword 'guest' may be arranged into three general categories:

- Supply-side actors: Interviewees considered guests in relation to different tourism supply-side actors such as hotels, hotel consortia, and DMOs, as well as product categories such as destinations and routes. According to interviewees, positioning may be a channel that connects guests with supply-side phenomena in tourism.

- Communication and distribution channels: New information and communication channels (internet) were issues that interviewees related to guests, in particular with regard to booking processes. 
- Travel motivation and travel behaviour: Interviewees associated guests with their needs and the development of these needs and wants (trends). Further issues concerned travel decision making and the role played by themes in this regard, as well as the interplay between tourism movement patterns and boundaries that may inhibit these movements.

\section{Discussion}

The presented results obtained from a meta analysis of previously conducted qualitative interview studies point to some considerations for future research on tourism network governance. The first part of the GABEK analysis reveals that it may be advisable to more intensively:

- consider innovation dynamics and relational dynamisms in networks as well as their governance;

- reflect on how network governance can deal with differences in networks such as multiple development speeds among actors and destinations;

- establish measures of network efficiency and discuss means to improve the efficiency of formal and informal network governance;

- consider the various means and instruments of network governance more extensively;

- reflect on the respective roles of DMOs at different levels of tourism governance and in relation to other actors in tourism.

The second part of the GABEK analysis considered associations of interviewees with the core demand concept of 'guest'. Starting from the assumption that existing research may have somewhat neglected the inter-connections between supply-side and demand-side networks, this analysis revealed that it may be advisable for future research on tourism network governance to:

- consider the guest side in relation to the supply side, thus always keeping the relationships, associations and boundary-spanning networks as well as the internetwork governance in mind;

- reflect on the possible impact of new communication technologies and the related evolution of distribution channels on networks and their governance; 
- relate research and practice in tourism to actual travel motivation and travel behaviour and determine what implication this may have for research on network governance in tourism.

\section{Conclusions and implications}

Comparing the literature review of achievements gained through research into network governance in tourism with the exploratory empirical spotlight on critical issues as perceived by tourism stakeholders, allows one to gain a sense of what still needs to be done in research on network governance. Based on both critical analysis of the theoretical accomplishments and the selected reflections on the practitioner side, the following gaps become apparent as topics for future research.

\subsection{Considering all sub-networks in tourism and their respective governance needs without} losing the big picture

Research on network governance in tourism should consider some of the so far neglected sub-networks and mutual connections of the tourism system. Additionally, it is pertinent to refer all empirical and conceptual analyses of sub-networks back to the context of the whole tourism system. Moreover, the inter-relationships and touch points between networks need to become a stronger focus. For instance, it might be fruitful to scrutinize the interplay between networks on the demand side (tourist-driven networks) and supply-side networks, as well as analyse the role of mediators in governing the inter-connection of these types of networks (inter-network governance).

\subsection{Considering media-based social networks (e-governance)}

New communication technologies and social media now established in broad segments of society have greatly increased consumers' relative networking capability and power.

Therefore, point 5.1 acquires additional, even more precise meaning. By appreciating the potentials and risks of new technologies (Sigala and Marinidis, 2012), research on network governance in tourism must find answers to the question of how to govern online distribution channels and online travel communities; the latter have gained wide control over content and distribution, and affect product development. For instance, some pioneering work delivered at 
ENTER-conferences (Hochmeister et al., 2013; Tammet et al., 2013) may benefit from being more closely combined with network and governance perspectives.

\subsection{Considering disparities within networks}

Networks in tourism are full of differences and imbalances. These disparities relate not only to disparities among actors and organizations, but also to those among regions and destinations (and the related characteristics, needs and goals). For instance, interlocking directorships may disproportionally increase the influence of particular individuals (Beritelli et al., 2013). Additionally, networks in tourism pose governance challenges concerning central-periphery structures (e.g. guided tour, route or city tourism - what about the surrounding countryside and hinterland?) (see Volgger et al., 2015). What happens with areas without destination management or with "non-tourism destinations" (Andergassen et al., 2013), where it is not economically worthwhile to invest in tourism? Often, disparities refer to uneven access to resources; a current example is the so-called digital divide, i.e. uneven access to digital communication infrastructures (Minghetti and Buhalis, 2009). Dealing with these and other kinds of disparities in tourism network governance is an issue that should be addressed by future research. First reflections on destination leadership (Pechlaner et al., 2014; Zehrer et al., 2014) provide a valuable basis for proceeding in this direction.

\subsection{Considering negative aspects of networking}

Related to point 5.3, and paralleling the recent call of Fyall et al. (2012), undesirable effects of networking have received much less attention than beneficial ones. Whereas critical appraisal of networks and network governance in tourism were more common in early studies (Bramwell and Lane, 2000; Hall, 1999), most recent literature often lacks a discussion of issues such as silent voices, mechanisms of inclusion and exclusion, (hidden) power differentials, a downplay of capital forms other than social capital, high costs of networking and inflexibility due to dense networks (for an exception see Airey and Ruhanen, 2013).

\subsection{Considering dynamism in and of networks and network governance}

Future research needs to redress the scarcity of dynamic analyses of tourism networks and their governance. Initial insights into the evolution of governance (Pforr et al., 2015; Volgger and Pechlaner, 2014) require detailed scrutinizing concerning, but not limited to, tendencies 
towards institutional and structural inertia (e.g. North, 1990), as well as path-creating processes that may overcome them. It is remarkable that only a few authors have investigated organizational transformations in tourism networks (e.g. Baggio and Sainaghi, 2011; Paget et al., 2010; Pforr et al., 2015). How can networks be kept dynamic and adaptable via specific governance schemes? What about network boundaries? How can network governance foster innovation?

\subsection{Considering the future role of network moderators}

As appears from the empirical analyses, more and more moderating actors in tourism networks, in particular DMOs, struggle with the tensions between guaranteeing broad participation of stakeholders, ensuring strategic alignment and providing room for innovation (i.e. for differences). Additionally, these moderators must deal with increasingly fragmented and dynamic travel behaviour of guests, which is supported by new distribution and information channels. Initial reflections on the future roles of network moderators based on the notion of variable geometries (Beritelli et al., 2014) are available. Generally, these accounts suggest increased flexibility can answer the challenges of complexity and differences. To grasp the future role of network moderators in tourism we may need to move beyond this starting point. Should we approach the issue even more candidly by not assuming a priori what should be kept variable in tourism governance: geometries and geographies, themes and motivations, attraction points or roles and functions? Or rather should we strive to create stabilities on the supply side in order to reduce complexity (for the sake of guests)?

Without doubt, intensive reflections on current relationships and mechanisms at the intersection point of supply and demand, of hosts and guests, are required. Then, as a second step, it is necessary to discuss the future role of moderators such as DMOs, tour operators, travel agencies, OTAs, GDS and search engines (and their interplay). In any case, the history of tourism research teaches that intermediation has tended to increase, rather than diminish, with the growing complexity of the tourism system (Kracht and Wang, 2010).

\subsection{Considering additional means of network governance}

As argued, formal power and knowledge, and to a lesser extent trust, have received some attention as means to govern networks in tourism. Overall, profound analyses of these means of governance are still to be delivered. For instance, given the fact that many tourismintensive areas are currently closing university departments in tourism research, it is pressing 
to better comprehend the contribution of knowledge generation (research) and knowledge distribution or knowledge transfer (education) in steering tourism networks.

The role of trust in promoting relational quality in the different sub-networks of tourism is acknowledged (Andreu et al., 2010), but remains insufficiently described. It might be necessary to investigate its relationship with innovation or professionalism, also including the guest side. For example, it is conceivable that higher professionalism in the host-guest relationship is accompanied by a reduction in the informal relationship quality between hosts and guests. Hence, trade-offs between trust and other means of governance might become evident in detailed investigations.

Finally, the exploratory empirical analysis revealed further potential means to steer networks. Thematic steering of networks and its organizational representation, as well as the role of branding in (supply-oriented) network governance, which so far have only been taken into account to a minor extent (Volgger et al., 2013), might prove to be fertile research areas. Could governance through common themes and brand values be partially decoupled from territorial elements and thus allow greater territorial flexibility and stronger market orientation?

\section{Outlook and limitations}

Tourism is a human practice. It is designed by humans for humans with their traits, attitudes and behaviour. This holds equally for tourism networks, which embed human agency but are at the same time transformed by human agency of specific persons. It might be wrong to loose this "human element" by perceiving tourism networks exclusively in terms of roles, functions and structures. Therefore, future research in this area should probably consider and promote perspectives that allow one to perceive the governance of tourism networks not only at the interface of structured roles and functions, but also with the aspect of transforming human agency.

Future research on governing tourism networks may thus offer sufficient insights into concepts and approaches that can link intangible and hidden structural framework conditions with tangible, concrete and transformative human agency such as leadership, entrepreneurship, trust, attitudes towards tourism and hospitality. A balanced combination of these more qualitative and exploratory approaches with more formal, technical and structural perspectives may indeed provide a promising path towards advancing our current 
understanding as well as how to practically implement effective, efficient and sustainable network governance in tourism at the interface between hosts and guests.

\section{References}

Airey, D. and Chong, K. (2010), "National policy-makers for tourism in China", Annals of tourism Research, Vol. 37 No. 2, pp. 295-314.

Airey, D. and Ruhanen, L. (2013), “Tourism policy-making in Australia”, paper presented at CAUTHE 2013, 11-14/02/2013, Christchurch, New Zealand.

Andergassen, R., Candela, G. and Figini, P. (2013), "An economic model for tourism destinations: Product sophistication and price coordination", Tourism Management, Vol. 37, pp. 86-98.

Andreu, L., Aldás, J., Bigné, J. E. and Mattila, A. S. (2010), “An analysis of e-business adoption and its impact on relational quality in travel agency-supplier relationships", Tourism Management, Vol. 31 No. 6, pp. 777-787.

Augustyn, M.M. and Knowles, T. (2000), "Performance of tourism partnerships: A focus on York", Tourism Management, Vol. 21 No. 4, pp. 341-351.

Bachinger, M. (2014), "Stakeholder Value in Regionalentwicklungsprozessen: Eine relationale Perspektive", in Pechlaner, H. and Reuter, C. (Eds.), Pionier-Regionen der Zukunft: Innovation, Qualität und Kooperation, Springer, Wiesbaden, pp. 33-69.

Baggio, R. (2008), "Symptoms of complexity in a tourism system”, Tourism Analysis, Vol. 13 No. 1, pp. 1-20.

Baggio, R. and Sainaghi, R. (2011), "Complex and chaotic tourism systems: Towards a quantitative approach", International Journal of Contemporary Hospitality Management, Vol. 23 No. 6-7, pp. 840-861.

Beaumont, N. and Dredge, D. (2010), "Local tourism governance: A comparison of three network approaches", Journal of Sustainable Tourism, Vol. 18 No. 1, pp. 7-28.

Beritelli, P., Bieger, T. and Laesser, C. (2007), "Destination governance: Using corporate governance theories as a foundation for effective destination management", Journal of Travel Research, Vol. 46 No. 1, pp. 96-107. 
Beritelli, P., Bieger, T. and Laesser, C. (2014), "The new frontiers of destination management: Applying variable geometry as a function-based approach", Journal of Travel Research, Vol. 53 No. 4, pp. 403-417

Beritelli, P. and Laesser, C. (2011), "Power dimensions and influence reputation in tourist destinations: Empirical evidence from a network of actors and stakeholders", Tourism Management, Vol. 32 No. 6, pp. 1299-1309.

Beritelli, P., Strobl, A. and Peters, M. (2013), "Interlocking directorships against community closure: A trade-off for development in tourist destinations", Tourism Review, Vol. 68 No. 1, pp. 21-34.

Bieger, T. (1996), Management von Destinationen, Oldenbourg, München.

Bieger, T. and Scherer, R. (2003), "Clustering und integratives Standortmanagement - von einem theoretischen Konzept zur konkreten Handlungsstrategie", in Scherer, R. and Bieger, T. (Eds.), Clustering - Das Zauberwort der Wirtschaftsförderung, Haupt, Bern, pp. 9-26.

Bodega, D., Cioccarelli, G. and Denicolai, S. (2004), "New interorganizational forms: Evolution of relationship structures in mountain tourism", Tourism Review, Vol. 59 No. 3, pp. $13-19$.

Bramwell, B. and Lane, B. (Eds.) (2000), Tourism collaboration and partnerships: Politics, practice and sustainability (No. 2), Channel View Publications.

Bramwell, B. and Lane, B. (2011), "Critical research on the governance of tourism and sustainability”, Journal of Sustainable Tourism, Vol. 19 No. 4-5, pp. 411-421.

Buhalis, D. (2000), "Marketing the competitive destination of the future", Tourism Management, Vol. 21 No. 1, pp. 97-116.

Buhalis, D. and Cooper, C. (1998), "Competition or co-operation: The needs of small and medium sized tourism enterprises at a destination level", in Laws, E., Faulkner, B. and Moscardo, G. (Eds.), Embracing and managing change in tourism, Routledge, London, pp. 324-346.

Candela, G. and Figini, P. (2010), "Destination unknown: Is there any economics beyond tourism areas?", Review of Economic Analysis, Vol. 2, pp. 256-271.

Carley, K.M., Diesner, J., Reminga, J. and Tsvetovat, M. (2007), "Toward an interoperable dynamic network analysis toolkit”, Decision Support Systems, Vol. 43 No. 4, pp. 1324-1347. 
Chung, C.N. and Luo, X. (2008), "Institutional logics or agency costs: The influence of corporate governance models on business group restructuring in emerging economies", Organization Science, Vol. 19 No. 5, pp. 766-784.

d'Angella, F. and Go, F. M. (2009), “Tale of two cities' collaborative tourism marketing: Towards a theory of destination stakeholder assessment", Tourism Management, Vol. 30 No. 3, pp. 429-440.

d'Angella, F., Carlo, M.D. and Sainaghi, R. (2010), “Archetypes of destination governance: A comparison of international destinations", Tourism Review, Vol. 65 No. 4, pp. 61-73.

Del Chiappa, G. and Presenza, A. (2013), "The use of network analysis to assess relationships among stakeholders within a tourism destination: An empirical investigation on Costa Smeralda-Gallura, Italy”, Tourism Analysis, Vol. 18 No. 1, pp. 1-13.

Dredge, D. (2006a), "Networks, conflict and collaborative communities", Journal of Sustainable Tourism, Vol. 14 No. 6, p. 562.

Dredge, D. (2006b), "Policy networks and the local organisation of tourism", Tourism Management, Vol. 27 No. 2, pp. 269-280.

Dredge, D. and Thomas, P. (2009), "Mongrel management, public interest and protected area management in the Victorian Alps, Australia”, Journal of Sustainable Tourism, Vol. 17 No. 2, pp. 249-267.

Flagestad, A. and Hope, C. A. (2001), "Strategic success in winter sports destinations: A sustainable value creation perspective”, Tourism Management, Vol. 22 No. 5, pp. 445-461.

Ford, R. C., Wang, Y. and Vestal, A. (2012), "Power asymmetries in tourism distribution networks", Annals of Tourism Research, Vol. 39 No. 2, pp. 755-779.

Fyall, A. and Garrod, B. (2005), Tourism marketing: A collaborative approach. Channel View Publications, Clevedon.

Fyall, A., Garrod, B. and Wang, Y. (2012), "Destination collaboration: A critical review of theoretical approaches to a multi-dimensional phenomenon", Journal of Destination Marketing \& Management, Vol. 1 No. 1, pp. 10-26.

Gephart, R. (2004), "Qualitative research and the Academy of Management Journal", Academy of Management Journal, Vol. 47 No. 4, pp. 454-62. 
Getz, D. and Jamal, T.B. (1994), "The environment-community symbiosis: A case for collaborative tourism planning", Journal of Sustainable Tourism, Vol. 2 No. 3, pp. 152-173.

Gretzel, U., Fesenmaier, D. R., Formica, S. and O'Leary, J. T. (2006), "Searching for the future: Challenges faced by destination marketing organizations", Journal of Travel Research, Vol. 45 No. 2, pp. 116-126.

Hall, C. M. (1999), "Rethinking collaboration and partnership: A public policy perspective", Journal of sustainable tourism, Vol. 7 No. 3-4, pp. 274-289.

Hochmeister, M., Gretzel, U. and Werthner, H. (2013), "Destination expertise in online travel communities", paper presented at ENTER Conference, 22-25/01/2013, Innsbruck, Austria.

Jamal, T.B. and Getz, D. (1995), "Collaboration theory and community tourism planning", Annals of Tourism Research, Vol. 22 No. 1, pp. 186-204.

Kale, P. and Anand, J. (2006), "The decline of emerging economy joint ventures: The case of India”, California Management Review, Vol. 48 No. 3, pp. 62-76.

Kaspar, C. (1991), Tourismuslehre im Grundriss, Bern.

Komppula, R. (2014), "The role of individual entrepreneurs in the development of competitiveness for a rural tourism destination-A case study", Tourism Management, Vol. 40, pp. 361-371.

Kracht, J. and Wang, Y. (2010), "Examining the tourism distribution channel: Evolution and transformation", International Journal of Contemporary Hospitality Management, Vol. 22 No. 5, pp. 736-757.

Kurtz, M.J. and Schrank, A. (2007), "Growth and governance: Models, measures, and mechanisms", Journal of Politics, Vol. 69 No. 2, pp. 538-554.

Laws, E., Richins, H. and Agrusa, J. F. (Eds.) (2011), Tourist destination governance: practice, theory and issues, Cabi.

Leiper, N. (1990), Tourism systems, Massey University, Business Studies Faculty.

Manente, M. and Minghetti, V. (2006), "Destination management organizations and actors", in Buhalis, D. and Costa, C. (Eds.), Tourism business frontiers: Consumers, products and industry, Elsevier Butterworth- Heinemann, Oxford, pp. 228-237. 
Mayntz, R. (2004), "Governance im modernen Staat", in Benz, A. (Ed.), Governance: Regieren in komplexen Regelsystemen, VS Verlag für Sozialwissenschaften, Wiesbaden, pp. $65-76$.

McKercher, B. (1999), “A chaos approach to tourism”, Tourism Management, Vol. 20 No. 4, pp. $425-434$.

Mingehtti, V. and Buhalis, D. (2010), "Digital divide in tourism", Journal of Travel Research, Vol. 49 No. 3, pp. 267-281.

Nordin, S. and Svensson, B. (2007), "Innovative destination governance: The Swedish ski resort of Åre", The International Journal of Entrepreneurship and Innovation, Vol. 8 No. 1, pp. 53-66.

North, D.C. (1990), Institutions, institutional change and economic performance, Cambridge University Press, Cambridge.

Novelli, M., Schmitz, B. and Spencer, T. (2006), "Networks, clusters and innovation in tourism: A UK experience", Tourism Management, Vol. 27 No. 6, pp. 1141-1152.

Nunkoo, R., Ramkissoon, H. and Gursoy, D. (2012), "Public trust in tourism institutions", Annals of Tourism Research, Vol. 39 No. 3, pp. 1538-1564.

Paget, E., Dimanche, F. and Mounet, J. (2010), “A tourism innovation case: An actor-network approach", Annals of Tourism Research, Vol. 37 No. 3, pp. 828-847.

Pavlovich, K. (2001), “The twin landscapes of Waitomo: Tourism network and sustainability through the Landcare Group", Journal of Sustainable Tourism, Vol. 9 No. 6, pp. 491-504.

Pavlovich, K. (2003), "The evolution and transformation of a tourism destination network: The Waitomo Caves, New Zealand”, Tourism Management, Vol. 24 No. 2, pp. 203-216.

Pechlaner, H., Herntrei, M., Pichler, S. and Volgger, M. (2012), "From destination management towards governance of regional innovation systems: The case of South Tyrol, Italy”, Tourism Review, Vol. 67 No. 2, pp. 22-33.

Pechlaner, H., Raich, F. and Beritelli, P. (2010), Special issue: Destination governance, Tourism Review, Vol. 65 No. 4, pp. 4-85.

Pechlaner, H. and Volgger, M. (2012), "How to promote cooperation in the hospitality industry: Generating practitioner-relevant knowledge using the GABEK qualitative research 
strategy”, International Journal of Contemporary Hospitality Management, Vol. 24 No. 6, pp. 925-945.

Pechlaner, H., Volgger, M. and Herntrei, M. (2012), "Destination management organizations as interface between destination governance and corporate governance", Anatolia: An International Journal of Tourism and Hospitality Research, Vol. 23 No. 2, pp. 151-168.

Pechlaner, H., Kozak, M. and Volgger, M. (2014), “Destination leadership: A new paradigm for tourist destinations?", Tourism Review, Vol. 69 No. 1, pp. 1-9.

Pechlaner, H., Beritelli, P. and Volgger, M. (2015), "Introduction: Emerging landscape of destination governance", in Pechlaner, H., Beritelli, P., Pichler, S., Peters, M. and Scott, N. (Eds.), Contemporary destination governance: A case study approach, Emerald, pp. vii.

Pforr, C. (2006), "Tourism policy in the making: An Australian network study", Annals of Tourism Research, Vol. 33, pp. 87-108.

Pforr, C., Pechlaner, H., Volgger, M. and Thompson, G. (2014), "Overcoming the limits to change and adapting to future challenges: Governing the transformation of destination networks in Western Australia", Journal of Travel Research, Vol. 53 No. 6, pp. 760-777.

Raich, F. (2006), Governance räumlicher Wettbewerbseinheiten. Ein Ansatz für die Tourismus-Destination, DUV, Wiesbaden.

Rhodes, R.A. (1997), Understanding governance: Policy networks, governance, reflexivity and accountability, Open University Press, Maidenhead and Philadelphia.

Ritchie, B. and Crouch, G.I. (2003), The competitive destination: A sustainable tourism perspective, CABI, Cambridge.

Ruhanen, L., Scott, N., Ritchie, B. and Tkaczynski, A. (2010), "Governance: A review and synthesis of the literature", Tourism Review, Vol. 65 No. 4, pp. 4-16.

Russell, R. and Faulkner, B. (2004), "Entrepreneurship, chaos and the tourism area lifecycle", Annals of Tourism Research, Vol. 31 No. 3, pp. 556-579.

Sammarra, A. and Biggiero, L. (2008), "Heterogeneity and specificity of inter-firm knowledge flows in innovation networks", Journal of Management Studies, Vol. 45 No. 4, pp. 800-829.

Scott, N., Baggio, R. and Cooper, C. (2008), Network analysis and tourism: From theory to practice (Vol. 35), Channel View Publications. 
Shih, H. Y. (2006), "Network characteristics of drive tourism destinations: An application of network analysis in tourism", Tourism Management, Vol. 27 No. 5, pp. 1029-1039.

Sigala, M. and Marinidis, D. (2012), "E-democracy and web 2.0: A framework enabling DMOs to engage stakeholders in collaborative destination management", Tourism Analysis, Vol. 17 No. 2, pp. 105-120.

Simon, H.A. (1962), "The architecture of complexity", Proceedings of the American Philosophical Society, Vol. 106, pp. 467-482.

Stevenson, N., Airey, D. and Miller, G. (2008), “Tourism policy making: The policymakers' perspectives", Annals of Tourism Research, Vol. 35 No. 3, pp. 732-750.

Stumpf, C. (1939), Erkenntnislehre: Band 1, Johann Ambrosius Barth, Leipzig.

Tammet, T., Luberg, A. and Järv, P. (2013), "Sightsmap: Crowd-sourced popularity of the world places", paper presented at ENTER Conference, 22-25/01/2013, Innsbruck, Austria.

Tinsley, R. and Lynch, P.A. (2008), "Differentiation and tourism destination development: Small business success in a close-knit community", Tourism and Hospitality Research, Vol. 8 No. 3, pp. 161-177.

Volgger, M., Pechlaner, H. and Pichler, S. (2013), "Verlieren Destinationen als Kooperationseinheiten an Bedeutung? Wechselwirkungen zwischen lokaler und überörtlicher Kooperation (Are destinations becoming less important as units of cooperation? Interactions between local and regional cooperation)", TW Zeitschrift für Tourismuswissenschaft, Vol. 5 No. 1, pp. 57-73.

Volgger, M. and Pechlaner, H. (2014), "Requirements for destination management organizations in destination governance: Understanding DMO success", Tourism Management, Vol. 41, pp. 64-75.

Volgger, M., Pichler, S. and Herntrei, M. (2015), "Italy", in Pechlaner, H., Beritelli, P., Pichler, S., Peters, M. and Scott, N. (Eds.), Contemporary destination governance: A case study approach, Emerald, Bingley, pp. 117-159.

Weidenfeld, A. (2013), “Tourism and cross border regional innovation systems", Annals of Tourism Research, Vol. 42, pp. 191-213.

Williamson, O.E. (1979), "Transaction-cost economics: The governance of contractual relations," Journal of Law and Economics, Vol. 22 No. 2, pp. 233-261. 
Zehrer, A., Raich, F., Siller, H. and Tschiderer, F. (2014), "Leadership networks in destinations", Tourism Review, Vol. 69 No. 1, pp. 59-73.

Zelger, J. (2000), “Twelve Steps of GABEKWinRelan: A Procedure for qualitative opinion research, knowledge organization and systems development", in Buber, R. and Zelger, J. (Eds.), GABEK 2: Zur qualitativen Forschung - On qualitative research, Studien-Verlag, Innsbruck, Wien, München, pp. 205-220.

Zhang, X., Song, H. and Huang, G. Q. (2009), "Tourism supply chain management: A new research agenda", Tourism Management, Vol. 30 No. 3, pp. 345-358. 